\title{
THE ROLE OF HISTORICAL AND ETHNOGRAPHICAL SOURCES IN THE BAGPIPE REVIVAL IN THE BALTICS
}

\section{VALDIS MUKTUPĀVELS}

This paper describes how the bagpipe revival process in Estonia, Latvia, and Lithuania, begun in the 1970s, has been influenced by historical and ethnographical sources, ethnomusicological scholarship, and certain personalities. Popular and academic views on the relationship between the instrument and ethnic identity - and contemporary developments in musical life-have undeniably had a considerable impact as well.

Keywords: traditional musical instruments, folklore movement, reinterpretation, bagpipe, folk revival concept, Estonia, Latvia, Lithuania
V̌́lanku je predstavljeno, kako so v Estoniji, Latviji in Litvi na proces oživljanja izdelave in igranja na dude vplivali etnomuzikologija, nekatere osebnosti ter na katere zgodovinske in etnografske vire so se pri tem sklicevali. $K$ oživljanju so nedvomno pripomogli tudi poljudni in akademski pogledi na razmerje med inštrumentom in etnično identiteto, a tudi sodobni razvoj glasbenega življenja.

Ključne besede: tradicionalna glasbila, folklorno gibanje, interpretacija, dude, koncept glasbeni preporod, Estonija, Latvija, Litva

The three Baltic countries-Estonia, Latvia, and Lithuania-have experienced similar cultural developments in the second half of the twentieth century, yet the bagpipe revival since 1970s displays significant regional differences in terms of intensity and forms. Bagpipes have become a more prominent component of musical life in the Baltics at the end of the twentieth century and the first two decades of the twenty-first century, and they are present at cultural and social events, but there has not been very much documentation and study of the instrument's contemporary situation. This study traces the important ideas, personalities, and events in bagpipe revival, which represents a conscious effort to study, practice, and develop the traditions associated with the instrument and its music. It describes how the revival process was influenced by historical and ethnographical sources, ethnomusicological scholarship, and personalities, as well as by other circumstances.

In this study, the historical comparison of piping traditions in all three countries is based on previously published works, including Igor Tónurist's "The Estonian Bagpipe" (1976), Valdis Muktupāvels's "Musical Instruments in the Baltic Region: Historiography and Traditions" (2002), "Über einige Musikinstrumente in litauischen und lettischen Bibeln des 16./17. Jahrhunderts und in der Alltagspraxis" (2010), Folk Music Instruments in Latvia (2018), Rūta Žarskienës “Užmirštieji muzikos instrumentai: dūdmaišis ir Lietuva” (2011), and others. Descriptions of bagpipe recordings from the early stages of revival are based on 7-inch vinyl discs and LPs, and more recent stages on selected CDs. The basic empirical material for the study has been collected as interviews of people active in bagpipe revival (performers, instructors, instrument makers, researchers) in all three countries: Kaspars Bārbals, Leanne Barbo, Antanas Fokas, Arūnas Lunys, Cätlin Mägi, Māris Muktupāvels, 
Vytautas Musteikis, Celia Roose, Sandra Vabarna, Eirimas Velička, and Evaldas Vyčinas, ${ }^{1}$ thus providing a strong insider's, or emic, view and knowledge. The author refers also to his own engagement in the revival since its early stages and continuous performance practice for four decades, a strong point here being his personal view of the general picture of the process and knowledge of the significant actors involved.

Taken together, the central research question here is how the popular and academic views on the relationship between folk instruments and ethnic identity on one hand and modern developments in musical life on the other have interacted with the revival process and thus affected bagpipes' contemporary situation.

\section{HISTORICAL AND ETHNOGRAPHICAL SOURCES OF PIPING IN THE BALTIC REGION}

It is generally accepted that a piping tradition has existed in the Baltics since the sixteenth century or earlier (Tónurist 1976; Brauns 2002; Žarskienè 2011). In some cases, scholars extend it to the fifteenth century (Allmo 1990: 298), fourteenth century (Tampere 1975: 22) or even as early as the thirteenth century (Jaago 2008: 49). Most of the historical evidence in the Baltics dates from the sixteenth to eighteenth centuries (Tónurist 1976; Muktupāvels 2002, 2018; Žarskienè 2011), thus marking this period as the "golden age" of piping. To understand better the role of bagpipes in traditional Baltic cultures, some references to the sources from that period are helpful. For instance, the Livonijas kronika (Chronicle of Livonia) by Balthasar Rusovs, which covers the period to 1583, contains several references to the use of musical instruments in sixteenth-century Livonia, ${ }^{2}$ particularly to the large bagpipe, which was well known in every village. Also, the situation with many bagpipes playing together is vividly described in the chronicle (Rusovs 1976 [1584]: 60-61). In later centuries, the similarity of Latvian and Estonian musical traditions — and particularly those of the bagpipes - is highlighted in at least one former part of Livonia, namely, Livland (Liivimaa EE, Vidzeme LV). In his 1777 essay about Livland and Estland, August Wilhelm Hupel writes: "The bagpipe is the most common — and presumably a very old —instrument for both peoples [Latvians and Estonians], which they make themselves and blow very rhythmically in two voices with a lot of skill”3 (Muktupāvels 2018: 23). Johann Christoph Petri in his 1809 work Neueste Gemählde von Lief-und Ehstland and Johann Georg Kohl in his 1841 work Die deutsch-russischen Ostseeprovinzen adopt a very similar stance and refer to bagpipes as the favorite or perhaps even most beloved instrument of the Latvians and

1 I am very grateful to all the interviewees for the information and opinions they shared.

2 The medieval Livonian Confederation is the predecessor of both Latvia and Estonia.

3 „Beyder Völker gemeinstes und vermuthlich sehr altes musikalisches Instrument ist der Dudelsack (Sackpfeife) den sie selbst machen und zweystimmig mit vieler Fertigkeit sehr taktmäßig blasen." 


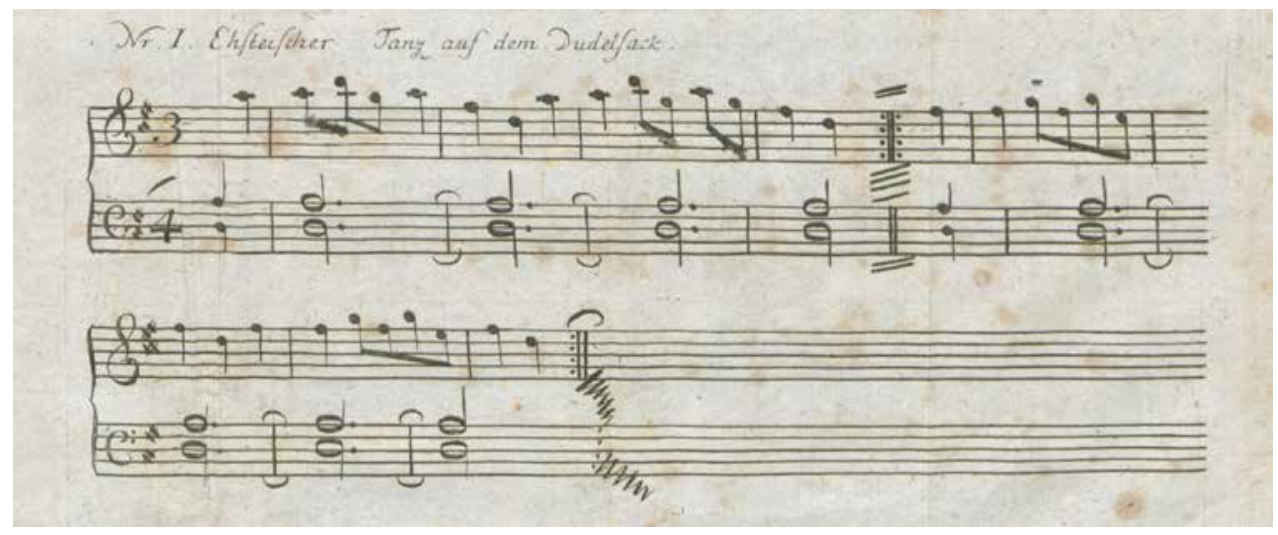

Bagpipe tune from Estonia (Hupel 1777, note supplement Nr. 1).

Estonians (Muktupāvels 2018: 24). Such a shared tradition was undoubtedly manifested in the design, manner of playing, repertoire, and use of the instrument.

Particularly interesting from the organology point of view are the first translations of the Bible into the Baltic languages. Thus, the Lithuanian manuscript was prepared in the Duchy of Prussia by Jonas Bretkūnas in 1591. The last page of the sixth volume contains a list of the Lithuanian and German names of thirteen musical instruments, in which large and small bagpipes are mentioned. The first complete translation of the Bible into Latvian was prepared by Ernst Glück in 1685 to 1691, in which the original Old Testament word nēbel is sometimes translated as Sohma-stabbules (= bagpipe; Muktupāvels 2010: 18-19). The translator surely looked for terms and expressions that were in current use and that could be properly understood by as many readers as possible.

A fairly rapid decline in piping took place at the end of the "golden period." In the Latvian case, that can be largely attributed to three factors (Muktupāvels 2018: 265-266), the first of which was legislation. In her book Latviešu deja (based on Carl Gottlob Sonntag's 1821 work Die Polizei für Livland), Elza Silin, writes:

Thus in 1753 the use of bagpipes was limited to smaller fairs. And on 15 December 1760 they were outlawed completely, with physical punishments for the player and a fine of five rubles for the master. The reasoning of the law was grounded in the following: the unruliness of drunken non-German servants tempts others to villainy. On 20 April 1765 this prohibition and punishments were renewed, and in 1773 a bagpipe player could still be fined three thalers. (Silina 1939: 131)

The second factor in the decline of bagpiping was intolerance based on religious ethics, with a special role played by the Unity of the Brethren (Herrnhuter) congregations in Vidzeme. Joahims Brauns writes about the disappearance of many older musical instruments in the eighteenth century and, based on Rudolph Minzloff's work Beiträge zur 
livländischen Sittengeschichte des 18. Jahrhunderts, tells about the writings in 1740 of von Ekesparre, a representative of the Brethren movement: "They completely destroyed their bagpipes, violins, and harps" (Brauns 2002: 62).

The third factor in the bagpipe's decline was the introduction of the violin. The first evidence of violins and violin playing dates to the turn of the seventeenth century, and by the eighteenth century the violin had become a beloved and popular instrument. It was probably a superior instrument as well, due to its broad diapason, suitability for various repertoires, and predictable tuning. Even though the bagpipe and violin existed side-by-side for a time and were even played together, the bagpipe era was nevertheless soon replaced by the violin era, as evidenced by such statements as "now [they] dance to fiddles, back then to bagpipes" from Latviešu Avizes in 1865, or "earlier in olden times [it was] horn and bagpipe blowers, later fiddle players" from Ernests Dinsbergs' 1890 article about wedding traditions in the Dundaga area in feudal times (Muktupāvels 2018: 265-266). The Estonian and perhaps also Lithuanian situations may be somewhat similar.

As a result, when the documentation of bagpipe traditions and collection of music and instruments began at the end of the nineteenth century, the tradition was still in

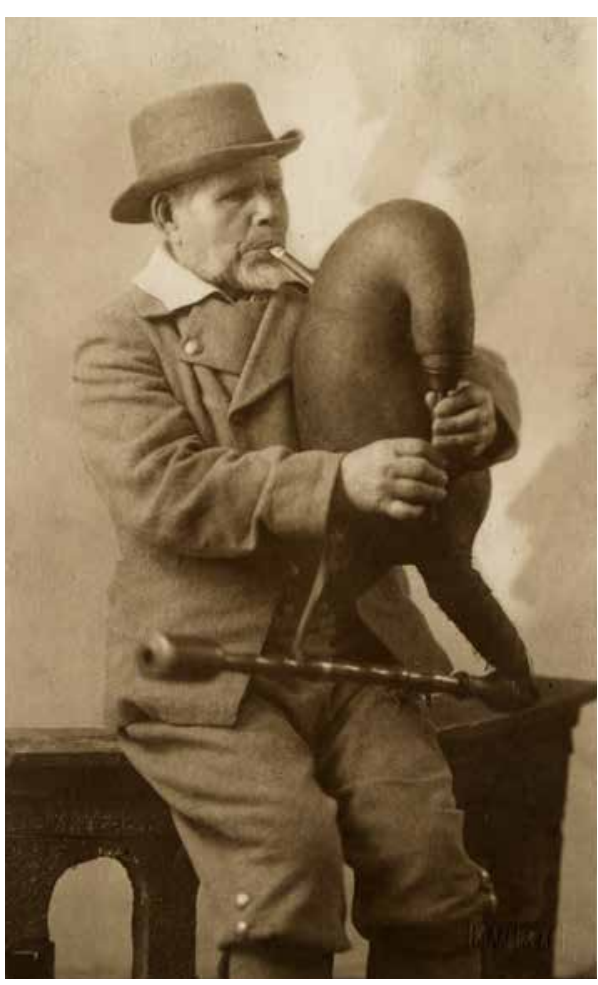

Historical bagpipe and piper Juhan Maaker from Hiiumaa, Estonia, 1928 (Photo: Karl Akel. Estonian Theatre and Music Museum ETMM 9424 MO 238:1/39:6). existence in only a few eastern Baltic regions. According to Igor Tónurist, "the bagpipe was longest preserved in West and North Estonia where folk music retained archaic characteristics for a longer time" (Tônurist 1976: 48); the scholar also specifies that in the 1950s there were still living bagpipers in Hiiumaa (op. cit.: 53). In the Latvian case, in the second half of the nineteenth century and the first half of the twentieth century bagpipes could only be found in western Kurzeme, especially in its Catholic enclave known as the Suiti region, where the last recordings were made in the 1930s, around Alūksne in northern Vidzeme, in eastern Latgale, and around Ilūkste in southeast of Latvia (Muktupāvels 2018: 266-267). As Rūta Žarskienè concludes, "in the second half of the nineteenth century they still knew the bagpipes in most of Lithuania, and in the first half of the twentieth century it was played at weddings, baptism, village dances, and other events" (Žarskienė 2011: 203). Memories about piping in eastern Lithuania, especially in the Labanoras area, were still alive in the 1960s. 


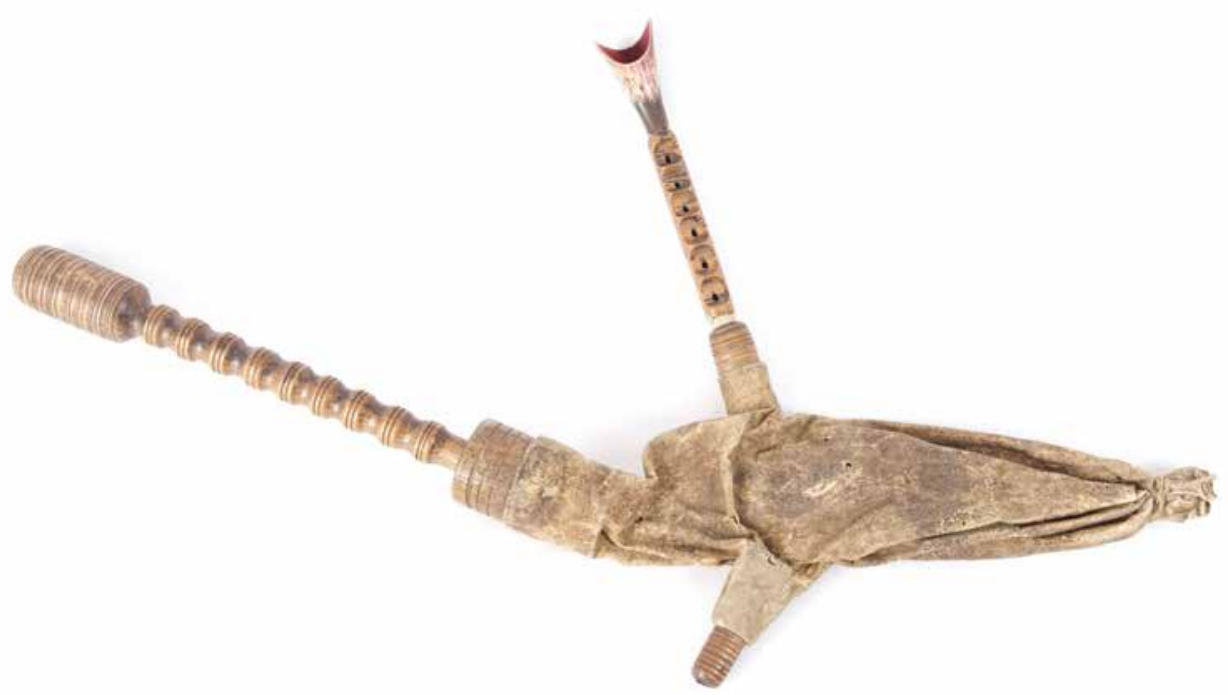

Historical bagpipe from Alsunga, Latvia, the last quarter of the 19th century (Photo: Aleksandrs Okonovs. National History Museum of Latvia CVVM 22290).

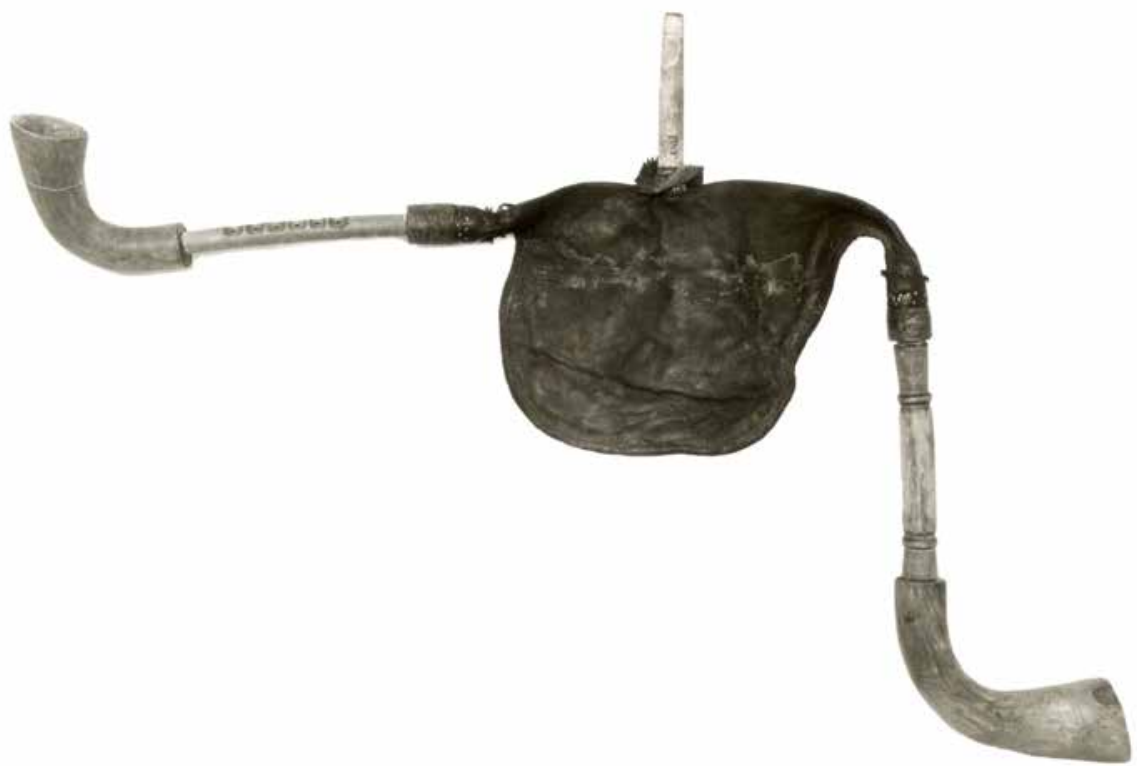

Historical bagpipe from eastern Lithuania (Photo: Zenonas Slaviūnas. Institute of Lithuanian Literature and Folklore LLTI 8972). 
Though there have been dedicated efforts to document the tradition in all three Baltic countries, the corpus of notated and recorded materials differs significantly. The Estonian bagpipe music collection is truly remarkable: the earliest notations are from the end of the eighteenth century, and today the Estonian Folklore Archive holds more than 140 recordings of bagpipe music on wax cylinders, shellac discs, and magnetic tapes played by seven players in the period from 1913 to 1956, and thus the playing of the last living bagpipers was well recorded. Various Estonian museums take pride in the possession of several instruments.

The traditional tuning of Estonian bagpipes is described as follows by Igor Tónurist:

The drones were tuned an octave or a fifth below the chanter keynote. The chanter had a diatonic scale, and then he provides four different tuning notations: 1. drones G2 D3, chanter F\#4 G4 A4 B4 C5 D5 E5; 2. drones A2 D3, chanter C\#4 D4 E4 F\#4 G4 A4; 3. drones A2 D3, chanter D4 E4 F\#4 G4 A4 B4; 4. drone C3, chanter B4 C5 D5 E5 F5 G5. (Tónurist 1976: 49-50)

The documentation of bagpipe music in Latvia did not have an auspicious beginning: the composer and folklorist Andrejs Jurjāns, during his notable field work expedition in the summer of 1891, met with a piper whose instrument, unfortunately, was kept in a shed that was full of hay at the moment, so he could not demonstrate his playing (Jurjāns 1980 [1892]: 116). The composer and folklorist Emilis Melngailis recorded approximately fifteen bagpipe melodies in the 1920s and 1930s in western Kurzeme, but most of that material was written down from singing instead of directly from playing the instrument. Only one piece, played by Pēteris Šeflers, was recorded by Latvian Radio; his playing was also included in the film Dzimtene sauc, commissioned by the Ministry of Interior Affairs and produced in 1935 .

As chanters from western Kurzeme tend to have five finger holes, the player must work within a hexachord, although its structure can change to a certain extent. The most commonly found scale in Emilis Melngailis' materials is G4 A4 B4 C5 D5 E5 or A4 B4 C\#5 D5 E5 F\#5; the same scale in Pèteris Šeflers's case has the upper four tones considerably lowered, almost by a whole tone. The only drone is tuned an octave or an eleventh (an octave and a fourth) lower than the chanter's lowest tone.

The documentation of Lithuanian bagpipe music has been more successful than that of the Latvian music, but still hardly to be compared with the Estonian situation. Rūta Žarskienè mentions as "the basic source of bagpipe repertoire" the nine phonograph recordings by Eduard Wolter in 1908, recorded in eastern Lithuania: six bagpipe solo tunes by Juozas Voldemaras and three tunes played by a bagpipe and violin duo (Žarskienè 2011: 211).

All these recordings are preserved in the Berlin Phonogram Archive. One bagpipe tune, played by Jurgis Gudynas with only the chanter and without the drone, was recorded in 1937 at the Lithuanian Folklore Archive in Kaunas. Three more tunes played by Antanas Žygas were recorded in 1964 in eastern Lithuania. Unfortunately, the quality of recordings 
was compromised, as Žygas had stopped playing more than 30 years ago and did not have his own instrument anymore. The folklorists assembled bagpipe parts borrowed from the museum, but the resulting instrument was impossible to tune (Žarskienè 2011: 205).

Notations of recorded music suggest the tuning of Lithuanian bagpipes: Juozas Voldemaras's bagpipe had an A drone and a chanter E4 G4 A4 B4 C\#5 D5 E5. The drone of the bagpipe given to Antanas Žygas was tuned to A and the chanter D4 E4 F\#4 G4 A4 B4 C\#5 D5. Thus, in both cases the chanter's scale spans an octave and the drone is tuned a fourth or fifth (plus octave) lower than the chanter's lowest tone.

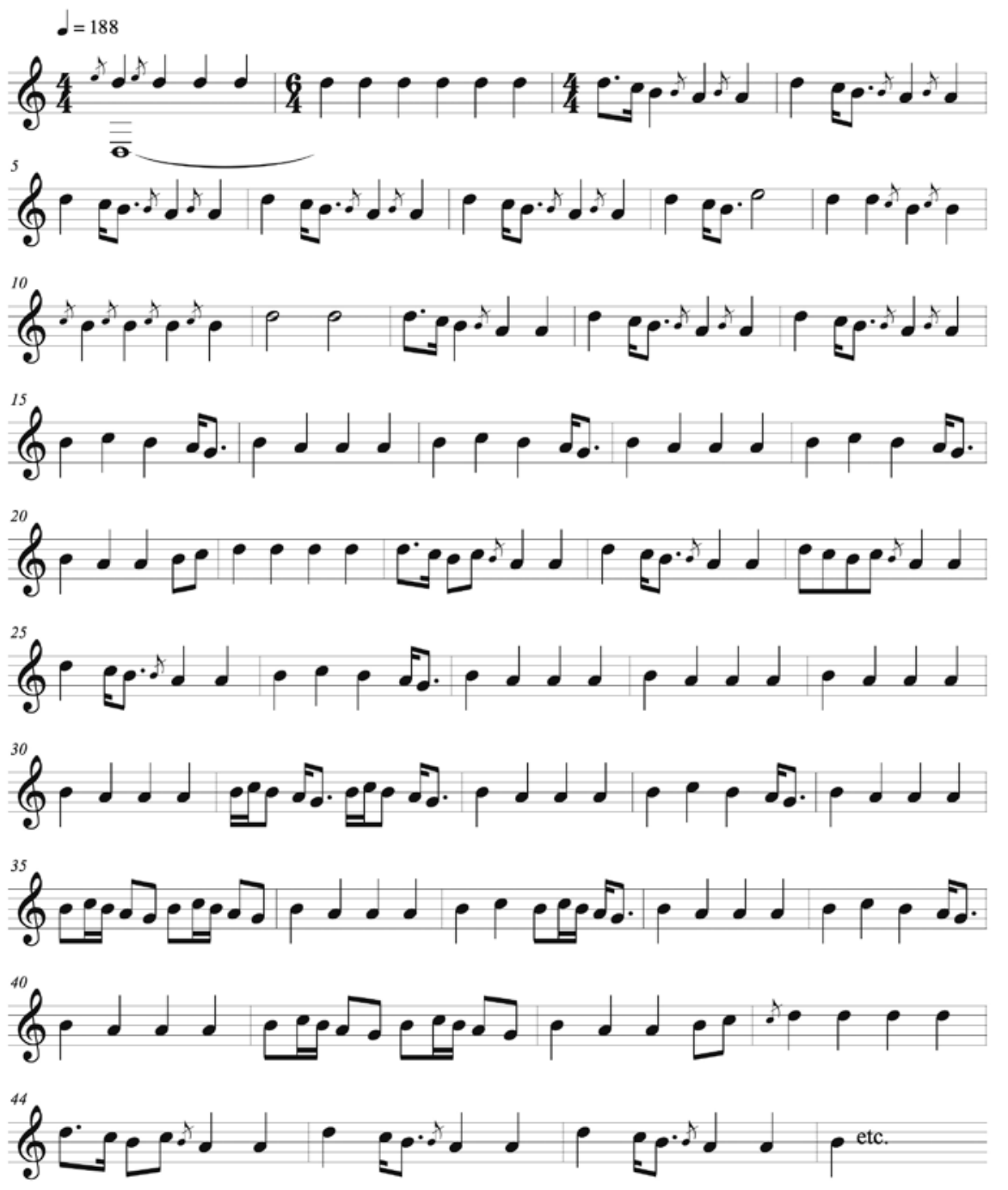

Bagpipe tune from Alsunga, Latvia, played by Pēteris Šeflers in 1934, transcribed by Valdis Muktupāvels in 1985 (Muktupāvels 2018: 320-321). 


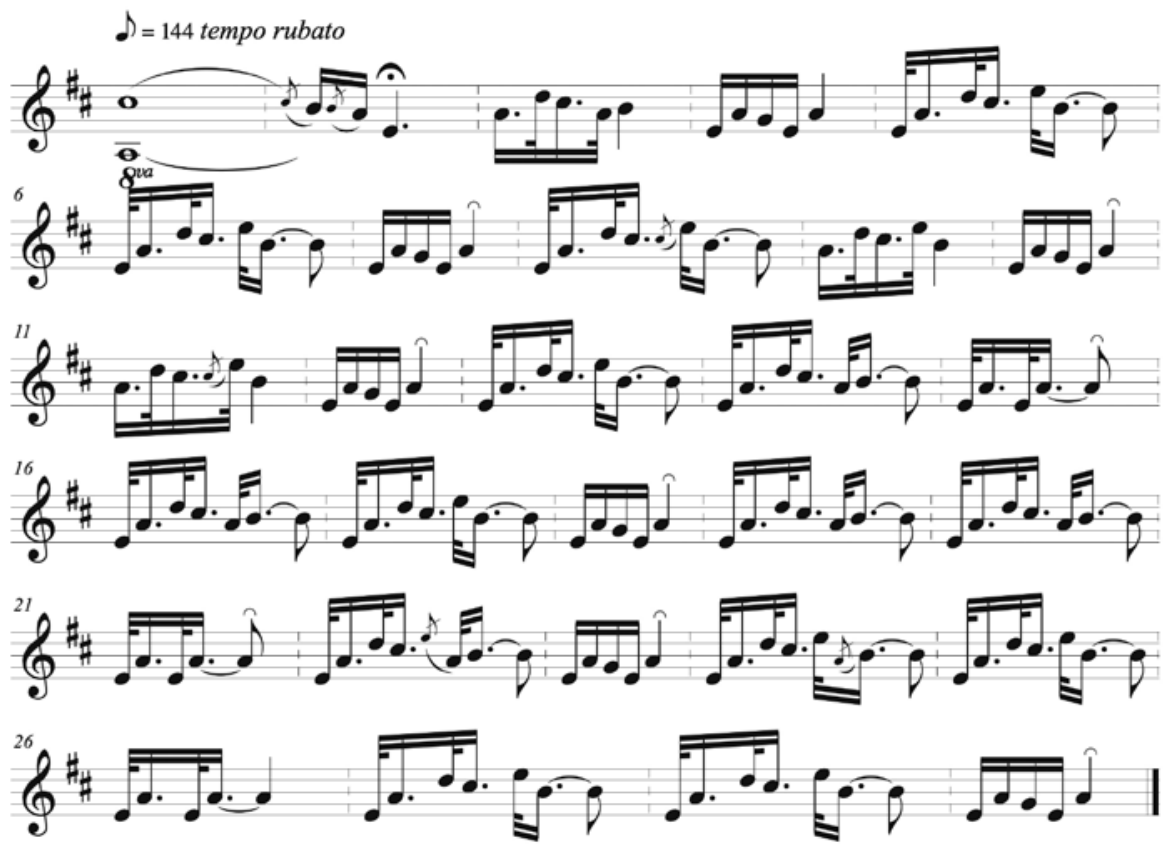

Bagpipe tune from Tverečius, Lithuania, played by Juozas Voldemaras in 1908, transcribed by Rūta Žarskienè in 2010 (Žarskienè 2013: 60).

THE REVIVAL'S ORIGINS:

IDEAS, PERSONALITIES, AND INFLUENCES

One of the first ideas of bagpipe revival was expressed by Emilis Melngailis. In his article "How one should revive the musical past" he discussed "a captivating idea to revive the music of ancient instruments" (Melngailis 19494: 23). At that time significant efforts were being invested in assembling a "folk instrument orchestra," and thus Melngailis' article seems to be a timely contribution to the stock of ideas regarding how this orchestra should be organized. The central place in this orchestra should be allocated to three groups of kokles, ${ }^{5}$ and a group of recorder-type pipes, drums, and other instruments could be added. He was quite positive about the bagpipe revival, but not in the framework of this folk instrument orchestra: "The bagpipe players, though not to be tolerated in a concert in closed space, will find their appropriate place in the future, and will perform noisily with their pipes,

4 The article seems to have been written in 1947, as one can conclude from Emilis Melngailis' remark "some 25 years ago (around 1922)."

5 Kokles - one of the most valued folk music instruments in Latvia, known also as the Baltic psaltery; a kind of a box zither with slightly fan-shaped strings. Modernized forms were introduced in music education and art music from the mid-twentieth century. 
two drones, and one usual, in various celebrations outdoors or in nature." (op. cit.: 25). Unfortunately, for some reason this did not come to pass and remained a mere intention.

In reviving bagpipes in Estonia there was almost no break in the tradition, since it was initiated by Olev Roomet, who "was greatly interested in the bagpipe and could acquire the basic methods of playing from still-living bagpipers" as early as the 1950s (Tónurist 1976: 53). This is how Igor Tônurist described the initial stage:

In the course of preparations for the republican dance festival in 1970 it was decided that the ancient art of playing on the bagpipe should be revived. 25 bagpipes were made by O. Roomet and Voldemar Süda, a master of musical instruments. In making the instruments an ethnographic example was followed in all authenticity. Only the bag was made of rubber and imitation chamois glued and stitched together. About 20 people (from the age of 14 to 70 !) learned the foundations of bagpipe-playing under the direction of O. Roomet. Their orchestra performed 2 pieces at the festival. Later the orchestra was dismissed, as it proved technically difficult to tune such number of instruments all at the same time. A part of the instruments were adopted for use by the ethnographic ensembles Leegajus and Leigarid. In Riidaja in the Valga district (South Estonia) a bagpipe quintette has existed for three years already. [...] A united ensemble of 10 bagpipes also took part in the dance festival of 1973. (Tónurist 1976: 53)

With Igor Tónurist as the artistic director, the Leegajus ensemble became a flagship of Estonian folklore movement in 1970s and 80s. Promoting authentic traditional music in general, they contributed significantly to establishing the status of bagpipe as an important traditional Estonian musical instrument. This was made especially visible when the ensemble released their LP Leegajus in 1975 with a large picture of group member Ain Sarv playing bagpipe on the cover (Leegajus 1975). Actually, only one track "Räditants" with bagpipe (plus other instruments) was included, but this recording spurred further interest in the instrument. Two years later Leigarid ensemble released their first vinyl 7" disc (Leigarid 1977) with three bagpipe tracks, combining Alfred Nurmik's bagpipe with other instruments and singing, as well as a bagpipe and a mouth harp duo in "Leika-Aadu Liisu." Five years later in their second disc (Leigarid 1982), two more bagpipe tracks "Tori labajalg" and "Targa rehealune" were included. The same year, the folk music ensemble Torupill from Riidaja released their album Pill kutsub with four bagpipe tracks "Harju valss," "Torupillipolka," "Veli, hella vellekene," and "Viru polka" (Riidaja rahvakunstiansambel Torupill 1982). Though the cover notes mention only Ants Taul as bagpipe player, several pipes together can be clearly heard, which may serve as evidence of Igor Tónurist's remark about a bagpipe quintet. Another vinyl 7" disc with three bagpipe tracks "Kivikasukas," "Torupillivalss," "Torupillilugu," released in 1983, was a recording of the Linnutaja ensemble, consisting of eight female pipers (Linnutaja 1983). This may be considered as a substantial move towards 
the establishment of women as pipers in modern Estonia. ${ }^{6}$ Moreover, an authentic recording "Loppevalts" from 1936 of the piper Jaagup Kilström from Kuusalu was included in the anthology of Estonian traditional music (The Folk Music of Estonia 1986).

The beginning of the bagpipe revival in Latvia was significantly influenced by Estonian developments. Valdis Muktupāvels_one of revival activists_obtained the Leegajus LP during a visit to Tallinn in 1978 and was emotionally and conceptually moved by the look and content of the album, offering the sounds of revived ancient instruments and performance of traditional vocal music styles. A year later, as a member of the Skandinieki folklore ensemble, he and Guntis Veiskats did their best to render playable two bagpipes that the ensemble leader had obtained from Estonia, apparently made by Voldemar Süda. Piping became an integral part of Skandinieki performances from this time. In addition, two albums with bagpipe music tracks were recorded: the vinyl 7" disc Senie balsi (Skandinieki 1982) with four bagpipe tracks "Apaḷais mēness," "Alšvangas dancis," "Dūdu balss," and "Diždancis," and the LP Divi duči rotalu kopā ar 'Skandiniekiem', which was published only in 1988 (Skandinieki 1988). Likewise, the anthology of musical folklore was published with one bagpipe music track (The Latvian SSR Musical Folklore 1986). By the early 1980s bagpipes were played by more participants of the Skandinieki ensemble, including by Valdis's brother Māris Muktupāvels. It was through frequent performances of this ensemble that bagpipes became a very familiar instrument in Latvia, and was soon played by more musicians. Another noteworthy moment in making bagpipes better-known in Latvia was the film Latviešu folklora. Gadskärtu dziesmas (Latviešu folklora 1983), which was commissioned by the Ministry of Education for Latvian folklore studies in general education and was distributed nationwide. The film was based on musical performances by the Savieši folklore ensemble, led by Valdis Muktupāvels. The twenty-minute film concludes with a masked mummers' procession with the mask of Death playing bagpipe in the foreground.

It is also possible to speak of a certain influence of Skandinieki on bagpipe revival in Lithuania, because their performances in Vilnius in 1982 sparked activity among local piping enthusiasts, foremost of whom is Evaldas Vyčinas. Having extensive knowledge and practice with other traditional instruments, he soon started to play the bagpipe brought to him from the Estonian maker Ants Taul in Riidaja, and to instruct new players in his folklore ensembles VISI and Jievaras, as well as others. There is little documentary evidence of piping in that period; just one track "Gyvatuks" with bagpipe, violin, double bass, and hammered dulcimer on the Jievaras album (Jievaras 1988) can be mentioned. Even the anthology of musical folklore, published at the same time as Estonian and Latvian ones (Folk Music of the Lithuanian SSR 1986), does not have a single bagpipe recording.

6 The ensemble is still active, and in 2018 they released the anniversary album Linnutaja 40 (Linnutaja 2018). 


\section{BAGPIPE MAKERS AND THEIR CONCEPTS}

Though there was a break in the bagpipe-making tradition in Estonia, the revival seems to have started at the point where some traditional feeling was still "in the air"; that is, memories about pipers, their instruments, and their music. The dance festival of 1970, infused with Roomet's and Süda's traditional knowledge, inspired the South Estonia Taul family from Riidaja to engage in bagpipe making. The bagpipe researcher and player Cätlin Mägi' writes: "Johannes and Ants Taul (father and son) started reviving the bagpipe making tradition based on the old bagpipes which were stored in archives. Thus, the shape and design of the bagpipes have the look of those that were used at the beginning of the nineteenth century" (Mägi 2015). In fact, Ants Taul introduced some innovations, for example, instead of traditional one or two drones, he made instruments with three drones tuned to G2, D3, G3: a basic bass tone, a fifth above, and an octave above. He also

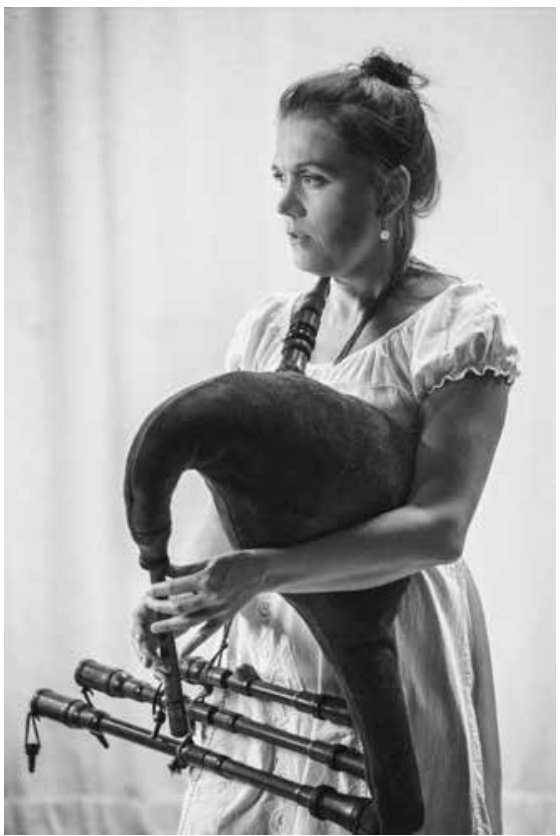

Cätlin Mägi with Andrus Taul's bagpipe (Photo: Maritta Anton, 2018). invented tuners for the drones: metal slides for shortening the vibrating part of the reed, ${ }^{8}$ with which one could not only adjust the drone, but change its pitch by a considerable interval, up to a fourth. Often the traditional diatonic seventh F\#4-E5 of the chanter was extended, adding one lower D4, or D4 and E4. With Ants's son Andrus taking over his father's techniques, bagpipe making has become an inherited trade. Andrus Taul's instruments visually follow a traditional pattern, whereas the tuning is more sophisticated: instruments are made with one, two, or three drones, and the pitch of the $\mathrm{D}$ drone can be tuned one tone up. Using double holes and two holes on the backside, several tones of the chanter's scale can be altered D4 E4 F\#4 (F4) G4 A4 (G\#4) (B b 4) B4 C5 D5 (C\#5) E5. Thus, the Taul family has established a sustainable standard for contemporary Estonian bagpipes.

There have been other bagpipe makers in Estonia, too, of whom the musician and brass band conductor Tarmo Kivisilla should be mentioned. He has made other instruments like the hiiukannel as well, but with his interest in spreading the piping tradition, he has taught instrument-making workshops in the last two decades, where several people learned to make their own bagpipe.

Maiden name Cätlin Jaago.

8 This unique construction is not evidenced, to the author's best knowledge, in any other bagpipes. 
Māris Jansons, one of the most productive bagpipe makers in Latvia, was involved in the traditional music revival in the mid-1980s. At some point he heard bagpipes performed live by an Estonian piper and also at the Baltica Festival in Lithuania in 1987, where a group from Brittany played their pipes, drums, and bombards. He was already making kokles and other instruments, and his impulse was to make a Latvian bagpipe. He studied the instruments in Latvian museums, trying to reproduce the same type: single reeds, a short chanter with five to eight ${ }^{9}$ holes, and a single drone. Satisfied with his results, he concluded: "I was going in the same directions as the traditional makers" (Paterson 2005: 39). Initially, his bagpipes were tuned similarly to Ants Taul's instruments: one or two drones G2, D3, chanter F\#4 G4 A4 B4 C5 D5 E5. In the first half of the 1990s he made several instruments with significantly lower chanters: one or two drones A2, D3, chanter C\#4 D4 E4 F\#4 G4 A4 B4 C\#5 D5. After seeing a seventeenth-century engraving of a bagpipe with two drones and a long conical chanter, ${ }^{10}$ he started to experiment with double reed chanters. To justify his disposition towards "non-traditional" double reed instruments, he claimed that if the old instrument makers had an idea, they "would immediately put it into their instruments without worrying whether it was 'traditional' . . . I I am trying to understand tradition, continue it and develop it; tradition is not in the museum. What is in the museum is dead and 'dead' is not traditional” (op. cit.: 39). Māris Jansons has also taught several bagpipe-making workshops, with about ten new participants in each.

Eduards Klints joined the folklore movement at about the same time and was impressed when he saw Māris Jansons' bagpipe. He began making pipes, by learning from his own experience and that of others, especially from Estonian maker Ants Taul, whom he visited for that purpose. He believes that with bagpipes "the sound and the Latvian identity - they go together. That is why I study early instruments in museums and try to reproduce them ... the search for one's roots, maintaining one's heritage" (Paterson 2005: 39). Eduards Klints's instruments have single reed chanter with up to seven/two holes, and sometimes double holes for half tones, resulting in the tuning D4 E4 F\#4 (F4) G4 A4 (G\#4) (Bb4) B4 C5 D5 (C\#5) E5. The one, two, or three drones, tuned G2, D3, and G3 respectively, are "topped with an apple-sized expansion chamber that markedly lowers the tone and enriches the timbre" (op. cit.: 39).

An effective impulse for making bagpipes in Lithuania was the activity of Evaldas Vyčinas, because he tried in 1983 to make new instruments based on Taul's sample. Vyčinas was not the first one to try; some experiments to make "elaborated" bagpipes were undertaken before, by Pranas Kupčikas for the Lietuva ensemble and by Arvydas Karaška and his father for the Ratilio ensemble, but the results were unsatisfactory. Since the mid-1980s such well-known folk music instrument makers as Jonas Bugailiškis and Egidijus Virbašius

9 From Mike Paterson's interview with Māris Jansons. In fact, bagpipe chanters in Latvian museums have five to six fingerholes.

10 This is probably the engraving in Adam Olearius's travel description Vermehrte Moscowitische vnd Persianische Reisebeschreibung, published in 1663. 


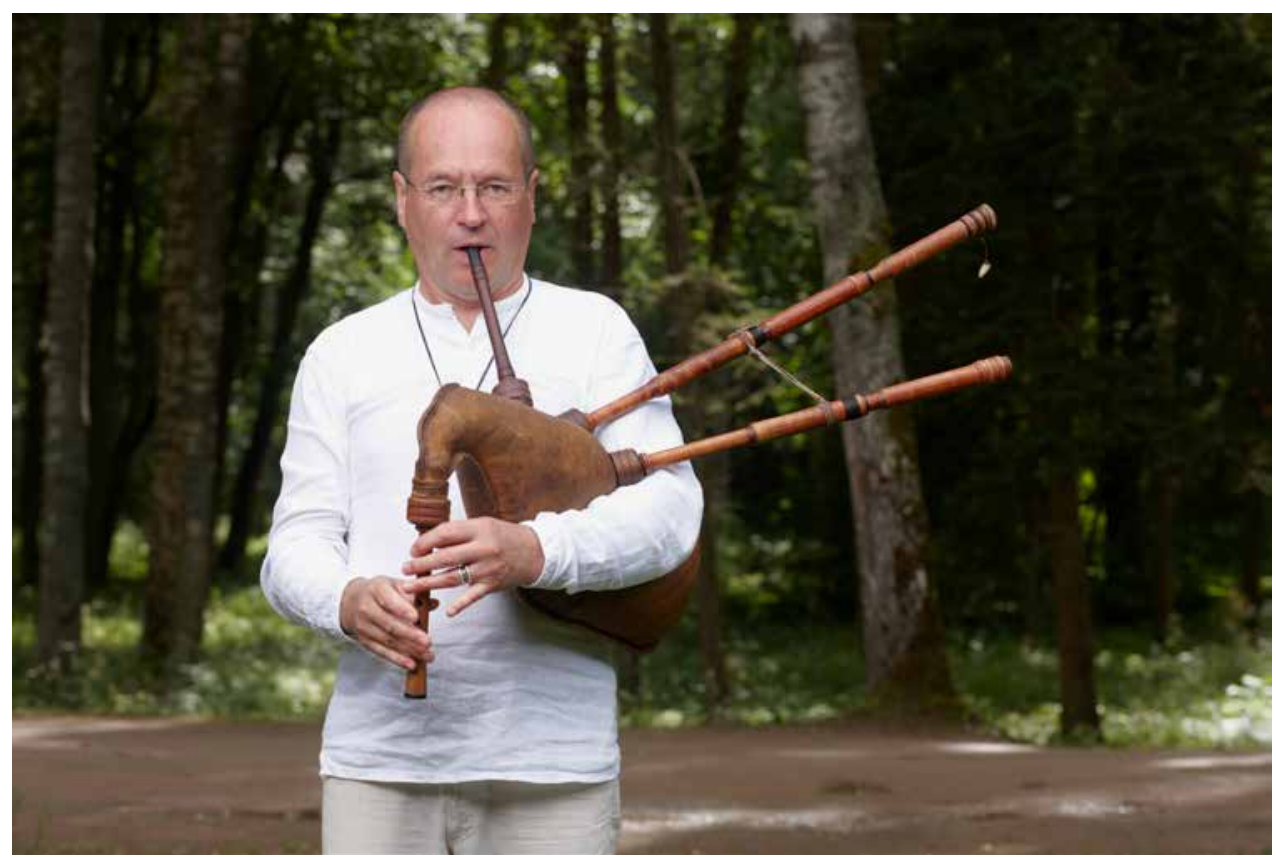

Valdis Muktupāvels with Māris Jansons’s bagpipe (Photo: Oskars Ludvigs, 2015).

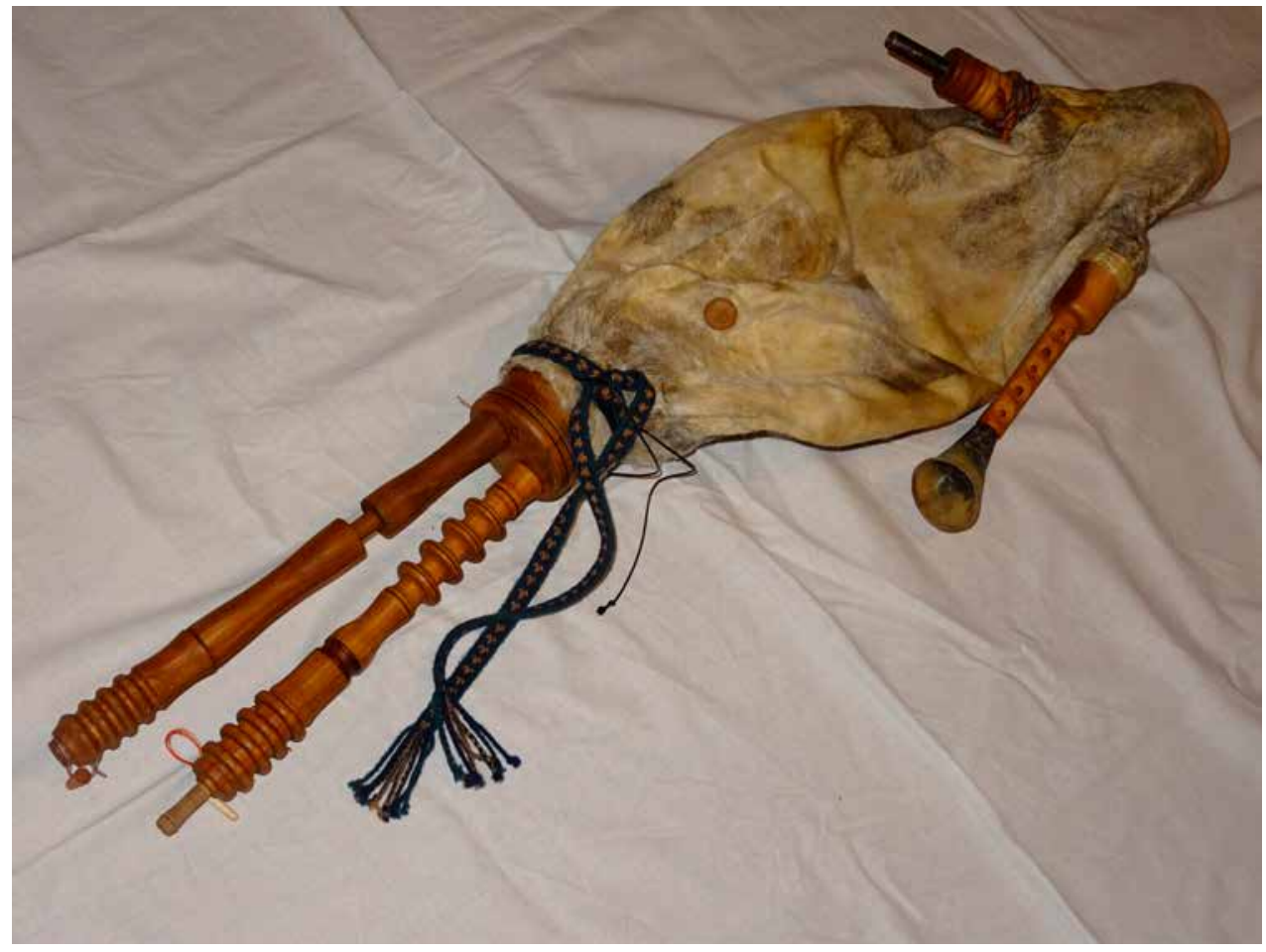

Eduards Klints's bagpipe (Photo: Eduards Klints. 2018). 
have made some bagpipes, but their production was not regular and the instruments did not receive the necessary appreciation.

Though the revived bagpipes in Belarus have made since the early 1980s by Ales' Los' (Inanec 2015), it was the beginning of the 1990s when the artist Todar Kaškurèvič started making his instruments and selling them in Lithuania as well. He tried to reproduce the instrument known as the "Vilnius bagpipe," and for this purpose studied instruments in Belarusian and Lithuanian museums. The historical connection to Lithuanian tradition and the quality of craftsmanship were the main reasons that Kaškurèvičs bagpipes were and still are in demand, making him the most productive bagpipe maker in Lithuania.

\section{SOME ASPECTS AFFECTING THE BAGPIPE CONCEPT IN THE CONTEMPORARY PERIOD}

It can be observed that, by and large, there are more similarities in Estonian and Latvian situations, whereas the Lithuanian concept seems to have more differences. The Estonian and Latvian commonalities have been shaped historically: common statehood in the form of medieval Livonia, membership in the Hanseatic League, the Swedish times, and the Baltic German cultural heritage. In his comprehensive study of bagpipes, Anthony Baines discusses the similarities between Swedish and Estonian bagpipes, and together with Latvian bagpipes attributes them to the northern or Baltic type: bell-less single-reed pipes with single chanters (Baines 1960: 70-71). Characterizing the Baltic type, he also mentions that the bass drone has "a bottle-shaped or bell-shaped termination with narrow orifice" (op. cit.: 90-91).

On the contrary, Lithuanian historical memory is rooted in the Grand Duchy of Lithuania, uniting present-day Lithuania and Belarus, as well as the period of the PolishLithuanian Commonwealth, so one would expect certain similarities between Lithuanian and Belarusian bagpipes. Though Anthony Baines does not refer to Lithuanian bagpipes directly, in his discussion of eastern European bagpipes he distinguishes the western type, mentioning "huge horn bells" and their distribution in Bohemia, Moravia, Poland, and White Russia [Belarus], and eastern Lithuania is also included on his map (op. cit.: 69-70). Rūta Žarskienè refers to Todar Kaškurèvič who suggests using the term "Lithuanian bagpipe" instead of "Belarusian bagpipe," thus pointing towards the common origin and distribution of both (Žarskienè 2011: 202).

Academic and popular publications display a significant difference in the Baltic countries in categorization of the bagpipe as an "ethnic" or "folk" music instrument. Since the end of the nineteenth century, when the first extensive lists of folk music instruments were published, Estonian and Latvian sources display a very similar attitude towards the bagpipe as old, inherited, and deeply rooted in local culture. For example, in the first long essay written in 1879 about Latvian folk music in olden times, Andrejs Jurjāns mentioned 
the trumpet, horn, drum, frame drum, pipe, bagpipe, dīkas [another type of bagpipe?], violin, kokles, and other instruments (Jurjāns 1980 [1879]: 18). The bagpipe is registered as old-time instrument alongside many others in the catalogue of the "Latvian Ethnography Exhibition" of the "10th All-Russia Archaeologists' Congress" in Riga in 1896, compiled by Rev. Vilis Plutte (Olavs) (Muktupāvels 2018: 27). The same is true of all significant Estonian and Latvian publications of the twentieth and twenty-first centuries, including such recent comprehensive works as Eesti rahvapille (Tónurist et al. 2008) and Folk Music Instruments in Latvia (Muktupāvels 2018).

The Lithuanian situation has developed differently. Composer and musicologist Juozas Žilevičius published several articles from 1927 to 1968 about Lithuanian folk instruments and proposed a classification according to their morphology and origin. From the viewpoint of origin, he distinguishes three groups: 1) instruments of local origin, 2) transmigrational instruments, which were brought to Lithuania, existed for some time and then disappeared, and 3) superstratial instruments, which were brought to Lithuania, were adopted, and became established in traditional musical life (Žilevičius 1927). It is not clear to which of these three categories he would attribute the bagpipe, but obviously it is not included in the local origin group. It is mentioned after such "migrated" instruments as the hammered dulcimer, monochord, and violin. His systematic approach has been highly appraised by organologist Romualdas Apanavičius:

[T] he first classification of the ethnic musical instruments proposed by this author in 1927 was not only the first attempt on the way of scientific systematization of the ethnic musical instruments but made a very big influence for latest systematizations of the ethnic musical instruments of other Lithuanian scientists. [sic] (Apanavičius 2013: 10)

Obviously, the idea had its appeal to Apanavičius and his colleague Marija Baltrénienė, and it underwent further development in their authoritative monograph about Lithuanian folk music instruments, which are formally classified following the Hornbostel and Sachs system, but complemented by two more categories: 1) objects utilized as musical instruments and lesser-known instruments, and 2) foreign (literally "of other nations") and classical instruments (Baltrènienè and Apanavičius 1991: 5). Bagpipes are included in the latter category, not in the class of aerophones, surprisingly (op. cit.: 163-164). Moreover, all the information about bagpipes is on one page, compared to nearly five pages about cowbells, for instance, thus indirectly hinting at intentional or unintentional marginalization of the former.

It should be mentioned that three years earlier Antanas Fokas presented and defended a bachelor's thesis on Lithuanian bagpipes at the Klaipeda University Music Conservatory (1988). The previous year also saw the publication of a twenty-three-page textbook Labanoro düda about one type of Lithuanian bagpipes, written by Klaipeda University 
ethnomusicologist Rimantas Sliužinskas for use at the Continuing Professional Education Institute for Cultural Workers (1990). Nevertheless, a comparatively small number of copies of this work (only 300 copies, compared to 10,000 copies of Baltrènienës and Apanavičius's book) had significantly less potential to influence popular views about the bagpipe.

The concept of bagpipes has been shaped to certain extent by folklore texts or, more specifically, by folksongs. This is the case especially in Latvia, where the corpus of materials reflecting the tradition is so meagre that it cannot meet the needs of willing enthusiasts. Three main Latvian folksong motifs are related to piping: firstly, pipes are made from an oak tree, cut before leaving for military service, and also drums are made of the same stem; secondly, pipes and drums are played together at various points in the wedding ceremony, and thirdly, thrice nine ${ }^{11}$ pipers play on a hilltop for a solemn occasion and also weddings. This last image, along with a short remark from Andrejs Jurjāns's 1891 fieldwork interviews, in which he was told that during a visit to Liepāja of the heir to the Russian throne [Alexander III?] an ensemble from the Suiti district performed "in a special music pavilion, with seven playing bagpipes and eight playing goat horns" (Jurjāns 1980 [1892]: 117) served as a strong argument for aggregating bagpipes into ensembles in contemporary times.

\section{THE CHANGING ROLE OF BAGPIPES SINCE 1970 S}

\section{IN EDUCATION}

The institutionalization of Estonian piping occurred when Viljandi Culture College ${ }^{12}$ introduced piping instruction along with that of other traditional instruments. With an emphasis on acquiring authentic tradition, they promoted mixing traditional music with jazz, thus creating a promising fusion that has been labelled ethno jazz or folk jazz. This is how one of the graduates, Cätlin Mägi, describes the implementation of piping tradition there:

At the beginning of the 1990s, Estonian music students started to revive the old music and instrument traditions using the model which had been employed, with great success, in Scandinavian music schools. The Viljandi Culture Academy under the guidance of Ando Kiviberg was instrumental in this and students were able to learn tunes from archive recordings so that they could imitate the style and techniques of the old players. The Estonian bagpipe has now been taken to another level by younger players, such as myself, Sandra Sillamaa [now Sandra Vabarna], and Juhan Suits, who had all studied at the Viljandi Culture Academy. (Mägi 2015)

11 Though several scholars treat 'trejdevinii' (thrice nine) as 'three times nine equals twenty-seven', mythology experts like Janina Kursite suggest that it is a number defined by ritual or an entity representing space and time (Kursite 1996: 119-127).

12 Since 2003 the Viljandi Culture Academy. 
There are also other institutions offering the study of Estonian bagpipes: the Estonian Academy of Music and Theatre, music schools in Tallinn, Tartu, and Viljandi, and others.

In addition to these regular opportunities to study piping there have been various courses and workshops. In 2000 a workshop in Tallinn was held for approximately twenty new pipers, with Igor Tónurist, Viljandi College teacher Celia Roose, and Tarmo Kivisilla as the main instructors. Most participants came with their own bagpipes, and the rest had the opportunity to buy Ants Taul's instruments. With the aim of bagpipe promotion in 2015 Sandra Vabarna initiated the project "100 Bagpipes," in which the main idea was to invite well-known people - musicians, actors, teachers, athletes, TV personalities, cultural figures - and teach them to play the instrument in just thirty minutes. The project lasted for a year, and the project episodes were filmed and distributed on social media, thus sharply increasing public interest in learning to play the bagpipes (Sillamaa 2015).

After enrolling in ethnomusicological studies at the Jāzeps Vìtols Latvian Academy of Music, students can specialize in playing of one of traditional instruments including bagpipe, yet very few have chosen this option. Interest in piping has been significantly stronger in the public sphere. For instance, to meet the increasing needs for some kind of teaching tools, the musician and piper Kaspars Bārbals has prepared and published a "teach yourself bagpipe" method, which is a set including an instructional book and a CD. The teaching material seems to have been prepared using some Highland piping instructional books and personal expertise of four Latvian pipers (Bārbals 2006). It has been used by piping enthusiasts mostly in a circle of Kaspars's friends and acquaintances, and remains unknown among the wider public.

The information gathered in this study indicates that there have not been very many institutional opportunities to learn piping in Lithuania, and thus the educational aspects have been left in the hands of amateurs to a large extent. Arūnas Lunys, an instrumental folk music specialist at the Lithuanian National Culture Centre, has prepared a compilation of 123 tunes, which are transcriptions of archive recordings and also traditional vocal and instrumental melodies that he considers bagpipe tunes or at least suitable for playing on bagpipes (2014). The compilation is accompanied by Rūta Žarskienës article about bagpipes in Lithuania (Žarskienè 2014). Like in Estonia and Latvia, there is some institutional support for traditional instrument workshops, and if there happens to be a piping activity, it is supported, too.

IN MUSICAL LIFE

Though the Estonian ensemble Linnutaja has existed since 1978, the very idea of a permanent ensemble with several bagpipes or a pipes-and-drums group has not been employed frequently. Yet, one such unit could be mentioned: a band of four pipers and a drummer that performs during national festivities, military parades, and other public events has existed for a long time. The band is associated with the Estonian paramilitary organization Kaitseliit, and its leader Ando Kiviberg is well-known folk musician and faculty member at 
the Viljandi Culture Academy. Evidently, besides being simply a noisy instrument suitable for playing outdoors, the bagpipe displays a certain aspect of Estonianness in this case.

From this viewpoint Latvia has some noteworthy developments. One of the first bagpipe ensembles in Latvia performed in a symbolically significant event: during the international folklore festival Baltica ' 88 in Riga it was secretly decided to publicly display the three Baltic countries' national flags, which were strictly prohibited during Soviet occupation. The opening ceremony in the grand hall of the Sports Palace started with a group of pipers making a circle in the middle of the arena and then all the three national flags were brought in and taken inside the circle. Thus, the instrument was strongly positioned as representative of national culture and resistance to the occupying power. The subsequent street procession was spontaneously headed by some pipers, violin players, and drummers, and since then the practice of piping in similar outdoor situation has become self-evident.

The pipers' ensemble Dūdinieki (literally “pipers" or "bagpipe players"), which brought together nine musicians, was founded by Māris Jansons in 1994, but disbanded after two years. The main reason was the problematic ensemble playing, because single-reed pipes in comparatively low registers produced a buzzing overtone that prevented clear perception of the melody line.

The idea about bagpipe ensemble was still "in the air," and in 2003 the pipes-anddrums group Aul,i, incorporating some pipers from the ensemble Düdinieki, was founded. This predominantly Latvian male group also features one Estonian female piper, Leanne Barbo. She learned piping while studying at Tartu University, and was invited to play with the group by Mikus Čavarts, the founder. Kaspars Bārbals, who was and still is the musical leader of the group, consciously introduced instruments with double reed chanters - mostly made by him, but also bought in Spanish Galicia and later-in Moravia. The drums were made by the ensemble members themselves: they were of impressive size and appearance, resembling wooden stems, thus establishing a clear reference to the folksong texts about making pipes and drums from the oak tree. Aul,i's music is created by the group members themselves, using varied drumming patterns and modified folksong melodies or their own compositions, but seldom traditional bagpipe tunes. The ensemble members wear stylized medieval stage costumes and they present their performance as "the pipes-and-drums music from Latvia." In popular perception the group represents a kind of Latvianness, and the bagpipes they play also conform to the concept of "Latvian pipes."

An interesting development has occurred in the traditional piping region in western Latvia, Suiti. With the initiative of the local Roman Catholic priest Andris Vasilevskis, several local people obtained their pipes from Eduards Klints and in 2014 founded the group Suitu Dūdenieki, with four pipers and a drummer. Notably, two male and two female pipers in the group clearly testify to the shift from a masculine-dominated piping tradition to a more balanced gender situation. With a reference to the status of bagpipe in the first Latvian Bible, the group has played in religious festivities, as well as on different local occasions, from weddings to drone music festivals, since then. 
Though bagpipes in Lithuania are played predominantly solo or with other instruments, a few performances with bagpipes groups are known. Composer Kęstutis Antanèlis created parts for three pipers in his oratorio Keturios lietaus šalys (1986), played by multiinstrumentalists Evaldas Vyčinas, Skirmantas Sasnauskas, and Vytautas Labutis; at that time, they all performed with Ants Taul's bagpipes. Several bagpipes together have performed at some of the "Nationwide Song and Dance Celebrations" since 1987. A public performance of several pipers usually accompanies the bagpipe meeting in Antanas at the Jonas Juška museum of ethnic culture, which takes place since 2008 in Vilkija, and ten to twenty pipers from Lithuania and other countries participate there. Six bagpipes and a brass band play together in album Kompromisai / Compromises (Sutaras+ 2018), compiled by Antanas Fokas.

The focus on traditional music and its fusion with jazz or other modern kinds of music in Viljandi Culture Academy has facilitated development of the piping tradition in two directions. Firstly, the recorded bagpipe tunes are not simply imitated, but new variations are created that preserve the style, characteristic techniques, and motifs. This is particularly present in Cätlin Mägi's two solo albums, In Bagpipe Tradition (Jaago 2002) and Soolo (Jaago 2010). Secondly, based on a solid mastery of the tradition, the creation of new material leads to a result that can be still recognized as related to the tradition. This trend can be illustrated by such innovative folkjazz bands as Ro:toro, in which bagpipes played by Cätlin and Sandra Vabarna interplay with a saxophone, or in the performance of “Trad.attack!", in which Sandra's bagpipe fuses with guitar and percussion.

The fusion of bagpipes and saxophones has also turned out to be fruitful in other Baltic countries. An ensemble of a bagpipe and saxophones has been present at several programs of the Riga Saxophone Quartet and Valdis Muktupāvels: "Oak" (2012-2014), "Flight of the Black Stork" (2014-2016), "Pictures at an Exhibition" (2016-2017), and "Sonorous Epochs" (2018). The interplay of two bagpipes and a saxophone permeates the Lithuanian album Tylos Labanoro (Kovera et al. 2005), which is presented as a part of a project supported by UNESCO and intended to revive a forgotten tradition of Labanoras bagpipe. The pipers are Gvidas Kovèra from Lithuania and Todar Kaškurèvič from Belarus, and the saxophone is performed by Petras Vyšniauskas, thus again proving the role of historical connections in contemporary revival processes.

Another type of contemporary music involving bagpipes is folk rock and folk metal. Such Latvian folk rock groups as The New Moon and Ilgi have used bagpipes as a strong accent connecting their music to the folkloric past. The bagpipes in the Estonian folk metal band Metsatöll and Latvian Skyforger represent the ancient heritage and also the spirit of a brave fight against the enemy both in mythical pagan times (when, in fact, there were no bagpipes yet) and in World War I (when, in fact, piping tradition was almost gone). The bagpipes in Skyforger were played by Kaspars Bārbals from 2004 until 2012, when he left the group because of the uneasy feeling during concerts of being overwhelmed by the massive guitar sound. 
Evidently, piping is becoming more and more varied in the Baltic countries, and in addition to traditional contexts the instrument is also used in other situations. To reflect this variety in Latvia, at the turn of the millennium Valdis Muktupāvels compiled the bagpipe music album Bagpipes in Latvia (Düdas Latvijā 2000) with seven different pipers and their music, both solo and in ensemble with other instruments and with singing. A year later the same album, now renamed The Bagpipes of Latvia (2001), was published by UK-based ARC Music company. A selection of Lithuanian bagpipe music Tir lir düda $d \bar{u} d a$ (2016), both archive recordings and various contemporary music projects, including bagpipe with a brass band, was compiled in 2016 by Arūnas Lunys and published by the Lithuanian National Centre for Culture.

The increased interest in piping in the Baltics has resulted in several notable festivals. In Estonia, every other year in August the Lahemaa Bagpipe Festival, founded by Ants Taul, takes place at Palmse Manor. The bagpipe event Bagpipes Plus (Torupill ja teine), where bagpipes are played alongside other instruments, such as fiddle, bowed harp, mouth harp, and others is a part of the Hanseatic Days festival in Viljandi. In Latvia, bagpipe music has been integral to the Drone Music Festival in Alsunga since 2004, and the fifth of these festivals took place in 2017. Bagpipe solos and ensembles are heard at medieval festivals, the most prominent of which has taken place in Cēsis since 1997. Bagpipe music is usually performed at Black-Horned Moon (Menuo Juodaragis), a festival of contemporary Baltic culture and alternative music in Lithuania.

\section{CONCLUSIONS}

The three Baltic countries — Estonia, Latvia and Lithuania_-share more than half a millennium of piping traditions, which had gradually disappeared by the mid-twentieth century. A comparatively well-documented bagpipe music and tradition-oriented education have promoted renewed attention to and respect for the revived piping tradition in modern Estonia.

In academic and popular discourse in Estonia and Latvia, the bagpipe tradition is mostly perceived as inherent to the local or native musical environment, whereas some authoritative sources in Lithuania treat it as "foreign" or "borrowed," and thus not really part of Lithuanian tradition. This approach has indirectly influenced the production of instruments, the study of bagpipe playing, and institutional support. The historical connections between Estonia and Latvia on the one hand and between Lithuania and Belarus on the other have certain impacts on developments in contemporary musical life.

With respect to bagpipe playing, some locally specific developments have occurred, such as the shifting of the male and female balance, ensemble play, and fusion with other instruments and contemporary musical styles. Nevertheless, international cooperation and globalization processes have also determined common tendencies in the development of bagpipe playing in the Baltic region. 


\section{REFERENCES}

Allmo, Per-Ulf. 1990. Säckpipan i Norden. Stockholm, Uppsala: AllWin hb.

Apanavičius, Romualdas. 2013. History and Problems of the Lithuanian Ethnic Instrumentology: Influence to the Movement of Revival of Ethnic Musical Instruments and Instrumental Music in the 20th C. - Beginning of the 21st C. Tradicija ir dabartis 8: 9-24.

Baines, Anthony. 1960. Bagpipes. Oxford: Pitt Rivers Museum and University of Oxford.

Baltrėnienė, Marija, and Romualdas Apanavičius. 1991. Lietuviu liaudies muzikos instrumentai. Vilnius: Mintis.

Bārbals, Kaspars. 2006. Dūdu spēles pašmācība. Riga: Lauska.

Brauns, Joahims. 2002. 2. Vijoḷmākslas agrīnais periods Latvijā (līdz XIX gs. vidum). In: Mārtinš Boiko (ed.), Joahims Brauns: Raksti. Studies. Schriften: Müzika Latvijä. Music in Latvia. Musik in Lettland. Riga: Musica Baltica, 49-100.

Fokas, Antanas. 1988.Düdmaišsis Lietuvoje. Bachelor's thesis. Klaipèda: State Music Conservatory, Klaipèda University. Hupel, August Wilhelm. 1777. Topografische Nachrichten von Lief-und Ehstland, II. Riga:Johann Friedrich Hartknoch.

Inanec, Snežana. 2015. Na hutor k dudarju. Available at: https://vk.com/wall-2038901_1725.

Jaago, Cätlin. 2008. Torupill. In: Igor Tõnurist et al. (eds.), Eesti rahvapille. Tallinn, Viljandi: Ajakirjade kirjastus, 46-50.

Jurjāns, Andrejs. 1980 (1879). Latviešu tautas mūzika. In: Laima Mūrniece (ed.), Raksti. Riga: Liesma, 17-24.

Jurjāns, Andrejs. 1980 (1892). Ievērojumi, latvju tautas mūzikas materiālus krājot. In: Laima Mūrniece (ed.), Raksti. Riga: Liesma, 91-123.

Kursīte, Janīna. 1996. Latviešu folklora mìtu spogulī. Riga: Zinātne.

Lunys, Arūnas, ed. 2014. Lietuviu liaudies instrumentine muzika: Muzika dūdmaišiui. Vilnius: Lietuvos liaudies kultūros centras.

Mägi, Cätlin. 2015. The Estonian Bagpipe - Torupill. Available at: http://www.bagpipesociety.org.uk/ articles/2015/chanter/summer/the-estonian-bagpipe-torupill/.

Melngailis, Emilis. 1949. Latviešu dancis. Riga: LVI.

Muktupāvels, Valdis. 2002. Musical Instruments in the Baltic Region: Historiography and Traditions. The World of Music 44 (3): 21-54.

Muktupāvels, Valdis. 2010. Über einige Musikinstrumente in litauischen und lettischen Bibeln des 16./17. Jahrhunderts und in der Alltagspraxis. In: Audronè Žiūraityte and Helmut Loos (eds.), Litauische Musik: Idee und Geschichte einer musikalischen Nationalbewegung in ihrem europäischen Kontext. Leipzig: Gudrun Schröder Verlag, 11-24.

Muktupāvels, Valdis. 2018. Folk Music Instruments in Latvia. Riga: University of Latvia Press.

Paterson, Mike. 2005. Republic of Latvia: Latvians Rekindle a Piping Heritage. Piping Today 18: 35-41.

Rusovs, Baltasars. 1976 (1584). Livonijas kronika., Transl. by Ed. Veispals. Grand Haven MI: AKA.

Siliņa, Elza. 1939. Latviešu deja. Riga: Latviešu folkloras krātuve.

Sillamaa, Sandra. 2015. 100 Torupilli! Available at: http://www.bagpipesociety.org.uk/articles/2015/ chanter/summer/100-torupilli/.

Sliužinskas, Rimantas. 1990. Labanoro dūda. Vilnius: Lietuvos kultūros darbuotojų tobulinimosi institutas.

Tampere, Herbert. 1975. Eesti rahvapillid ja rahvatantsud. Tallinn: Eesti raamat. 
Tõnurist, Igor. 1976. The Estonian bagpipe. In: René de Maeyer (ed.), The Bagpipes in Europe. Brussels: Museum of Musical Instruments, 47-54.

Tõnurist, Igor et al. (eds.). 2008. Eesti rahvapille. Tallinn, Viljandi: Ajakirjade kirjastus.

Žarskiené, Rūta. 2011. Užmirštieji muzikos instrumentai: dūdmaišis ir Lietuva. Tautosakos darbai 42: 194-222.

Žarskienè, Rūta. 2013. Bagpipe in Lithuania. In: Ilma Grauzdiṇa (ed.), Mūzikas zinātne šodien: Pastāvīgais un mainigais, zinātnisko rakstu kräjums $V$. Daugavpils: Daugavpils universitātes akadēmiskais apgāds "Saule", 50-70.

Žarskiené, Rūta. 2014. Dūdmaišis Lietuvoje. In: Arūnas Lunys (ed.), Lietuvių liaudies instrumentinè muzika: Muzika düdmaišiui. Vilnius: Lietuvos liaudies kultū ros centras, 5-13.

Žilevičius, Juozas. 1927. Lietuvių liaudies muzikos instrumentai. Iliustruotoji Lietuva 22 (75): 177-180.

\section{AUDIO RECORDINGS}

Dūdas Latvijā. 2000. Dūdas Latvijā: Bagpipes in Latvia (CD), compilers Valdis Muktupāvels and Māris Muktupāvels. UPE CD 017.

Folk music of the Lithuanian SSR. 1986. Folk Music of the Lithuanian SSR: Anthology, Authentic Folk-Lore (LP), compiler Genovaitè Četkauskaitè. Melodija M30 46847008.

Jaago, Cätlin. 2002. In Bagpipe Tradition (CD). Forwards Studio.

Jaago, Cätlin. 2010. Soolo (CD). Cätlin Jaago.

Jievaras. 1988. Jievaras: Liaudies folklorinis ansamblis (LP). Melodija C30 27445009.

Kovera, Gvidas et al. 2005. Tylos Labanoro: Tranquilities of Labanoras (CD). Gvidas Kovera and Petras Vyšniauskas.

Leegajus. 1975. Estonian Folk Songs and Instrumental Pieces (LP). Melodija C30 05807-8.

Leigarid. 1977. Leigarid (vinyl 7" disc). Melodija C32-04941-2.

Leigarid. 1982. Leigarid (vinyl 7" disc). Melodija C32-17717-8.

Linnutaja. 1983. Linnutaja (vinyl 7” disc). Melodija C32-18983-003.

Linnutaja. 2018. Linnutaja 40 (CD). H. Valk.

Riidaja rahvakunstiansambel Torupill. 1982. Pillkutsub: Eestikülakapelle (vinyl7" disc). Melodija M32-41813-4.

Skandinieki. 1982. Senie balsi: Latviešu tautas instrumentāla müzika (vinyl7" disc). Melodija C32-16487-8.

Skandinieki. 1988. Divi duči rotal̦ kopā ar "Skandiniekiem”(LP). Melodija C30-18795-6.

Sutaras+. 2018. Kompromisai/Compromises: Lithuanian FolkMusic (CD), compiler Antanas Fokas. KukūSMF 057.

The bagpipes of Latvia. 2001. The Bagpipes of Latvia (CD), compilers Valdis Muktupāvels and Māris Muktupāvels. ARC Music EUCD 1692.

The folk music of Estonia. 1986. The Folk Music of Estonia: Anthology, Authentic Folk-Lore (LP), compiler Ingrid Rüütel. Melodija M30 46729004.

The Latvian SSR musical folklore. 1986 (corrected to 1988). The Latvian SSR Musical Folklore: Anthology, Authentic Folk-Lore (LP), compilers Arnolds Klotiņš and Vilis Bendorfs. Melodija M30 46913005.

Tir lir dūda dūda. 2016. Tir lir dūda dūda: Dūdmaišio melodijos: Lietuvių liaudies instrumentinè muzika (CD), compiler Arūnas Lunys. Vilnius: LNKC. 
FILMS

Dzimtene sauc, film director Aleksandrs Rusteiķis, bagpipes played by Pēteris Šeflers, Ministry of the Interior, 1935.

Latviešu folklora. Gadskārtu dziesmas, film director Andris Slapiņš, bagpipes played by Valdis Muktupāvels, Riga Film Studio, 1983.

\section{VLOGA ZGODOVINSKIH IN ETNOGRAFSKIH VIROV PRI OŽIVLJANJU DUD NA BALTIKU}

Raziskava razkriva, kako so v Estoniji, Latviji in Litvi na proces oživljanja igranja in izdelave dud vplivale etnomuzikologija in nekatere osebnosti ter na katere zgodovinske in etnografse vire so se pri tem sklicevali. Avtor se osredinja na različne vidike, na pomembne mejnike $v$ procesu preporoda, na specifičen razvoj v vsaki državi, npr. na izdelavo dud, njihovo vlogo $v$ izobraževanju in glasbenem življenju, na spajanje tradicionalne glasbe z drugimi vrstami glasbe ter naposled na njihov pomen $v$ zvočnih posnetkih in drugih medijih.

$O$ tradicionalnih dudah $v$ Estoniji obstaja razmeroma veliko dokumentov, $v$ Litvi in Latviji pa bistveno manj. Prav tako se je oživljanje igranja in izdelave dudv Estoniji začelo precej prej. $V$ akademskem in popularnem diskurzu $v$ Estoniji in Latviji tradicijo dud večinoma dojemajo kot tipično za lokalno ali domače glasbeno okolje; $v$ Litvi pa jo nekateri veljavni viri obravnavajo kot "tujo" ali "sposojeno", tj., da dude niso del litovske tradicije. Posredno je to vplivalo tudi na izdelovanje dud - v Estoniji in Latviji jih delajo sami, najvec litovskih dud pa prihaja iz Belorusije. Študij igranja na dude je v Estoniji institucionaliziran, medtem ko v Latviji obstaja le nekaj potencialne institucionalne podpore, $v$ Litvi pa je to večinoma ljubiteljska dejavnost.

Vigranju na dude odsevajo tudi nekateri specifičnimi dogodki na Baltiku. Na sodobnem estonskem prizorišču prevladujejo ženske, v Latviji igrajo tako moški kot ženske, v Litvi pa nastopajo le moški. Ansambli dud so bili ustanovljeni v Latviji, v Estoniji in Litvi je znanih manj primerov skupinskega igranja na dude. Vpopularni glasbi danes labko slisimo dude skupaj s saksofoni ali drugimi instrumenti, so pa tudi v folk rock ali folk metal glasbenih zasedbah. $V$ veliki meri pa so osnovne trende oživljanja igranja dud na Baltiku določili tako mednarodno sodelovanje kot procesi globalizacije.

Prof. Dr. Valdis Muktupāvels

Department of Latvian and Baltic Studies, Faculty of Humanities, University of Latvia

Visvalža iela 4a, Rīga LV1050, Latvia, vm@lu.lv 